\title{
FLAVONOIDS AND OTHER BIOACTIVE PHENOLICS ISOLATED FROM Cenostigma macrophyllum (LEGUMINOSAE)
}

\author{
Clayton Q. Alves e Jorge M. David* \\ Instituto de Química, Universidade Federal da Bahia, 40170-280 Salvador - BA, Brasil \\ Juceni P. David e Cristiane F. Villareal \\ Faculdade de Farmácia, Universidade Federal da Bahia, 40170-280 Salvador - BA, Brasil \\ Milena B. P. Soares \\ Centro de Pesquisas Gonçalo Moniz, Fundação Oswaldo Cruz, 400295-001 Salvador - BA, Brasil \\ Luciano P. de Queiroz \\ Departamento de Ciências Biológicas, Universidade Estadual de Feira de Santana, 44031-460 Feira de Santana - BA, Brasil \\ Rosane M. Aguiar \\ Departamento de Química e Exatas, Universidade Estadual do Sudoeste da Bahia, Jequié - BA, Brasil
}

Recebido em 1/9/11; aceito em 6/12/11; publicado na web em 31/1/12

\begin{abstract}
This work describes the phytochemical study of stem bark and leaves of Cenostigma macrophyllum Tul. (Leguminosae). Through usual chromatographic techniques were isolated bergenin as the primary compound of the stem bark of and from the leaves gallic acid, methyl gallate, ellagic acid, quercetin, quercetin-3-O- $\beta$-D-glucopyranoside, quercetin-3-O-(6"- $O$-galloyl)- $\beta$-D-glucopyranoside (tellimoside), quercetin-3-O-(6"-O-E-p-coumaroyl)- $\beta$-D-glucopyranoside (helichrysroside), agathisflavone and vitexin were obtained. The isolates were identified by spectroscopic data analysis, and bergenin showed dose-related antinociception when assessed in acetic acid-induced writhing in mice.
\end{abstract}

Keywords: Cenostigma macrophyllum; Cenostigma gardnerianum; antinociceptive activity.

\section{INTRODUCTION}

Cenostigma macrophyllum Tul. (Leguminosae) is a plant popularly known as "canela-de-velho," "caneleiro" and "catingueira"l that can be found in the Brazilian "cerrado" and "caatinga" regions. ${ }^{2}$ This native species is important to the people of the arid northeastern Brazilian region ("caatinga") as an alternative source of cattle feed during dry seasons. ${ }^{3}$ Cenostigma is a small genus composed of three species of trees and shrubs. ${ }^{4}$ The leaves, stem bark and flowers of species of this genus are also used as folk medicines to treat stomach and intestinal disorders. ${ }^{5}$ Cenostigma macrophyllum was previously used in studies of chemical composition and pharmacological activities. The aqueous leaf extract of C. macrophyllum showed anti-ulcer activity, and the ethanol extract presented antimicrobial, anti-inflammatory and antinociceptive activities. ${ }^{6}$ This paper reports the results of a phytochemical study of the bioactive methanol extracts of leaves and stem bark from C. gardnerianum. Once the $\mathrm{MeOH}$ extracts presented rich in phenolics the stem bark $\mathrm{MeOH}$ extract was submitted to by chromatographic techniques and provided gallic acid besides bergenin (1) as the main compound (2.9\%) while the $\mathrm{MeOH}$ extract of leaves furnished the following, in addition to gallic acid and methyl gallate: ellagic acid, quercetin (2), quercetin-3-O- $\beta$-D-glucopyranoside, quercetin-3-O-(6"-O-galloyl)$\beta$-D-glucopyranoside (3), quercetin-3- $O$-(6"- $O$-E- $p$-coumaroyl)- $\beta$-Dglucopyranoside (4), agathisflavone (5) and vitexin (Figure 1). This is the first report of bergenin (1) having analgesic activity in mice.

\section{EXPERIMENTAL}

\section{General experimental procedures}

Column chromatography (CC): silica gel 60 (200-400 mesh,

\footnotetext{
*e-mail: jmdavid@ufba.br
}

Merck), Sephadex LH-20 (Pharmacia) and Polyamide 6 (50 $\mu \mathrm{m}$; Baker). Thin-layer chromatography: silica gel $60 \mathrm{PF}_{254}$ plates (Merck). NMR spectrometry: Varian spectrometer, model Gemini 2000, $\delta$ in ppm rel. to $\mathrm{Me}_{4} \mathrm{Si}, J$ in $\mathrm{Hz}$; LC-MS: Mass Spectrometer LCMS2010 (70 eV) Shimadzu, in $\mathrm{m} / \mathrm{z}$.

\section{Plant material}

Plant material was collected in the surroundings of Casa Nova, Bahia, Brazil. Voucher specimen (L. P. de Queiroz 9147) was deposited at the Herbarium of the Universidade Estadual de Feira de Santana (Bahia, Brazil) under \# HUEFS 78.424.

\section{Extraction and isolation}

The leaves (900 g) and stem bark (1200 g) were extracted with $\mathrm{MeOH}(3 \times 4 \mathrm{~L}$ and $10 \mathrm{~L}$, respectively). After filtration, the solvent was removed, and the residue was partitioned with $\mathrm{CHCl}_{3}: \mathrm{MeOH} / \mathrm{H}_{2} \mathrm{O}$ (1/9). The methanol of the hydroalcoholic phase was removed, and the aqueous phases were partitioned with EtOAc. During concentration of the EtOAc extract from stem bark ( $30.70 \mathrm{~g}$ ), a crystalline solid was precipitated, and after separation by filtration compound $\mathbf{1}$ (896 mg), it was obtained by recrystallization with methanol.

The EtOAc extract of leaves $(26.07 \mathrm{~g})$ was purified by $\mathrm{CC}\left(\mathrm{SiO}_{2}\right.$; $\mathrm{CHCl}_{3} / \mathrm{MeOH}$ 1:0, 9:1, 8:2, 7:3, 1:1, 0:1) to furnish eleven fractions: Fr.1-Fr.11. Fr. $4(894 \mathrm{mg})$ was purified by $\mathrm{CC}\left(\mathrm{SiO}_{2} ; \mathrm{CHCl}_{3} / \mathrm{MeOH}\right.$ $1: 0,9: 1,8: 2,7: 3,1: 1,0: 1)$ resulting the pure compounds methyl gallate $(313.2 \mathrm{mg})$ and ellagic acid (2) $(25 \mathrm{mg})$. Fr.7 was identified as gallic acid (743.7 mg). Fr.8 was purified by CC (1. polyamide 6, $\mathrm{H}_{2} \mathrm{O} / \mathrm{MeOH}$ 8:2, 6:4, 1:1, 3:7, 0:1; 2. Sephadex LH-20; $\mathrm{CH}_{2} \mathrm{Cl}_{2} / \mathrm{MeOH}$ $1: 1,0: 1)$, yielding the compounds quercetin $(2,45 \mathrm{mg})$, quercetin3- $O$ - $\beta$-D-glucopyranoside (152 mg), 3 (39.5 mg), 4 (35.3 mg), 5 $(38.2 \mathrm{mg})$ and vitexin $(36.7 \mathrm{mg})$. 
<smiles>COc1c(O)cc2c(c1O)[C@@]1(C)O[C@H](CO)[C@@H](O)[C@H](O)[C@]1(C)OC(=O)c1cc(O)cc(O)c1-2</smiles>

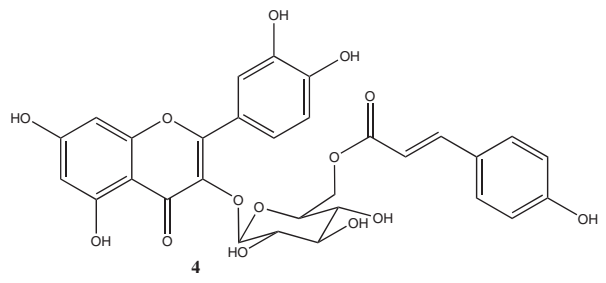<smiles>O=c1cc(-c2ccc(O)cc2)oc2cc(O)c(-c3c(O)cc(O)c4c(=O)cc(-c5ccc(O)cc5)oc34)c(O)c12</smiles>

Figure 1. Bergenin and other isolates of C. macrophyllum

\section{Bergenin}

Solid crystalline (m. p. $\left.238-240^{\circ} \mathrm{C}\right) .[\alpha]_{\mathrm{D}}^{20}-37.0^{\circ}$, (c $\left.0.20, \mathrm{MeOH}\right)$, MSAPCI (neg.): 327 [(M-H)-]. IR $v_{\text {Max }}\left(\mathrm{cm}^{-1}\right): 3423,3389,3247$, 3204, 2951, 2896, 1701, 1613, 1464, 1348, 1335, 1234, 1092, 1071, 991, 858 and 765 (KBr). ${ }^{1} \mathrm{H}$ NMR (300 MHz, CD 3 OD): $\delta 7.07$ (s, H-9), 4.95 (d, $J=10.5$ Hz, H-1), 3.35-4,09 (m, H-11-14); 3.90 (s, $\mathrm{H}-15),{ }^{13} \mathrm{C}$ NMR (75 MHz, CD $\left.\mathrm{OD}\right): \delta 119.37$ (C-5), 117.24 (C-10), 152.28 (C-6), 142.21 (C-8), 149.38 (C-7), 111.04 (C-9), 165.79 (C-1), 74.19 (C-4), 75.58 (C-11), 81.34 (C-3); 71.82 (C-12), 82.98 (C-13), 62.63 (C-14), 60.93 (C-15).

Quercetin-3-O-(6"-O-galloyl)- $\beta$-D-glucopyranoside (3)

Yellow powder. APCIMS (neg.) $\mathrm{m} / \mathrm{z}$ (int.) $[\mathrm{M}-\mathrm{H}] \mathrm{m} / \mathrm{z}, 615$ (100); 598(35); 463(20); 301 (32); 284 (32). ${ }^{1} \mathrm{H}$ NMR (300 MHz, CD $30 D$ ): $\delta 7.56$ (d, $\left.J=2.4 \mathrm{~Hz}, \mathrm{H}-2^{\prime}\right) ; 7.54$ (m, H-6'); 6.94 (s, H-2"'/H-6"'); 6.72 (d, $\left.J=9.0, \mathrm{H}^{\prime} 5^{\prime}\right) ; 6.33$ (d, $\left.J=2.1 \mathrm{~Hz}, \mathrm{H}-8\right) ; 6.17$ (d, $J=2.1 \mathrm{~Hz}$, H-6); 5,19 (d, J=7.5 Hz, H-1"); 4.32-4.02 (m, H-6"); 3.34-3.80 (m, H-2"-H-5"). ${ }^{13} \mathrm{C}$ NMR (75 MHz, CD $\left.\mathrm{OD}\right): \delta 158.3$ (C-2); 135.2 (C-3); 179.3 (C-4); 162.8 (C-5); 99.9 (C-6); 165.8 (C-7); 94.9 (C-8); 159.3 (C-9); 105.6 (C-10); 123.0 (C-1'); 117.2 (C-2'); 145.7 (C-3'), 149.7 (C-4'); 115.9 (C-5'); 123.6 (C-6'); $104.2\left(\mathrm{C}-1^{\prime \prime}\right) ; 75.7$ (C-2"); 78.0 (C-3"); 71.5 (C-4"); 75.9 (C-5"); 64.3 (C-6"); 121.3 (C-1"'); 110.2 (C-2"'/C-6"'); 146.3 (C-3"'/C-5"'); 139.7 (C-4"').

Quercetin-3-O-(6"-O-E-p-coumaroyl)- $\beta$-D-glucopyranoside (4) Yellow powder. APCIMS (neg.) $m / z$ (int.) $[\mathrm{M}-\mathrm{H}] \mathrm{m} / z, 609$ (100);
594 (15); 462 (27); 447 (27); 301 (38). ${ }^{1} \mathrm{H}$ NMR (300 MHz, CD $30 D$ ): $\delta 7.60\left(\mathrm{~d}, J=2.1 \mathrm{~Hz}, \mathrm{H}-2^{\prime}\right) ; 7.57$ (dd, $J=8.4$ and $2.1 \mathrm{~Hz}, \mathrm{H}-6$ '); 7.39

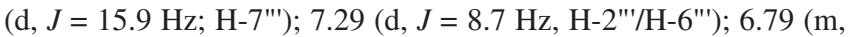
$J=8.4 \mathrm{~Hz}, \mathrm{H}-5$ '); 6.79-6.60 (indt, H-3"'/H-5"') 6.27 (d, $J=2.1 \mathrm{~Hz}$, H-8); 6.11 (d, $J=2.1 \mathrm{~Hz}, \mathrm{H}-6) ; 6.06$ (d, $\left.J=15.9 \mathrm{~Hz} ; \mathrm{H}-7{ }^{\prime \prime}\right) ; 5.25$ (d, $J=7.2 \mathrm{~Hz}, \mathrm{H}-1 "$ ); 4.32 (dd, 11.7 and $2.1 \mathrm{~Hz}, \mathrm{H}-6 "$ ); 4.23-4.35 (m, H-2"-H-5"). ${ }^{13} \mathrm{C}$ NMR (75 MHz, CD $\left.\mathrm{OD}\right): \delta 158.3$ (C-2); 135.2 (C-3); 179.4 (C-4); 162.9 (C-5); 100.0 (C-6); 165.9 (C-7); 94.8 (C-8); 159.1 (C-9); 105.6 (C-10); 123.1 (C-1'); 117.4 (C-2'); 145.9 (C-3'), 149.7 (C-4'); 115.9 (C-5'); 123.4 (C-6'); 103.9 (C-1"); 75.7 (C-2"); 78.1 (C-3"); 71.8 (C-4"); 75.9 (C-5"); 64.4 (C-6"); 127.1 (C-1"'); 131.2 (C-2"'); 116.8 (C-3"'); 161.1 (C-4"'); 131.3 (C-5"'); 116.8 (C-6"'); 146.5 (C-7"'); 114.8 (C-8"'); 168.9 (C-9"').

\section{Animals}

Experiments were performed on male Swiss Webster mice (30-35 g) from the Animal Facilities of the Centro de Pesquisas Gonçalo Moniz. Animals were individually housed at $24 \pm 1{ }^{\circ} \mathrm{C}$ under a 12:12-h light-dark cycle (lights on at 07:00 AM) with free access to chow and tap water until the day of the experiment, when only water was made available to them. Each animal was used only once. Animal care and handling procedures were in accordance with the International Association for the Study of Pain guidelines for the use of animals in pain research ${ }^{7}$ and the Institutional Animal Care and Use Committee - FIOCRUZ 26/2009-1. All efforts were made to minimize the number of animals used and any discomfort. All behavioral testing was performed between 8:00 a.m. and 4:00 p.m.

\section{Writhing test}

Antinociceptive doses of bergenin were determined in mice using the writhing test. Acetic acid $(0.8 \% \mathrm{v} / \mathrm{v}, 10 \mathrm{~mL} / \mathrm{kg})$ was injected into the peritoneal cavities of mice that were then placed in a large glass cylinder, and the intensity of nociceptive behavior was quantified by counting the total number of writhes occurring between 0 and 30 minutes after the stimulus injection. ${ }^{8}$ The writhing response consists of a contraction of the abdominal muscle together with a stretching of the hind limbs. Antinociceptive activity was expressed as the writhing score over $30 \mathrm{~min}$.

\section{Data analysis}

Data are presented as means \pm SEM of measurements made on 6 animals in each group. Comparisons across three or more treatments were made using one-way ANOVA with Tukey's post hoc test. All data were analyzed using Prism 4 computer software (GraphPad, San Diego, USA). Statistical differences were considered to be significant at $\mathrm{P}<0.05$.

\section{RESULTS AND DISCUSSION}

Compound 1 was isolated as a crystalline solid, and the molecular formula was established as $\mathrm{C}_{14} \mathrm{H}_{16} \mathrm{O}_{9}$ based on spectral data obtained by negative APCI-MS $(\mathrm{m} / z 327[\mathrm{M}-\mathrm{H}])$ and ${ }^{1} \mathrm{H}$ and ${ }^{13} \mathrm{C}$ NMR analysis, including DEPT. The analysis of IR spectrum of bergenin permitted to assign the presence of hydroxyl groups and a lactone carbonyl conjugate group by the characteristic stretching frequencies. The ${ }^{1} \mathrm{H}$ NMR spectra of $\mathbf{1}$ confirmed the identification of this compound by the presence of the characteristic singlet in a pentasubstituted aromatic ring at $\delta_{\mathrm{H}} 7.07$ beside the peaks at $\delta(\mathrm{H}) 4.94(\mathrm{~d}, J=10.5 \mathrm{~Hz}, 1 \mathrm{H})$, and $\delta(\mathrm{H}) 3.35-4.09(\mathrm{~m}, 6 \mathrm{H})$ characteristic of hydrogens attached to oxygenated carbons, indicating the presence of a sugar moiety. The HMQC and HMBC experiments permitted to confirm the localization 
of the glucosyl moiety through the correlation of annomeric hydrogen $\left(\mathrm{H}-1^{\prime}\right)$ and $\mathrm{C}-5\left(\delta_{\mathrm{C}} 117.24\right)$, confirming the $\mathrm{C}$-heteroside linkage to this compound. The location of the methoxyl group was established through the long range correlation of methoxyl hydrogens $\left(\delta_{\mathrm{H}} 3.90\right)$ and the peak at $\delta_{\mathrm{C}} 142.21(\mathrm{C}-7)$. The stereochemistry of the sugar moiety was assigned by coupling constants observed by the ${ }^{1} \mathrm{H}$ NMR spectrum and the $\mathrm{C}-13$ shifts. All data obtained from ${ }^{13} \mathrm{C} \mathrm{NMR}$ spectra were directly compared with the literature for bergenin, ${ }^{9}$ the structure of which was previously confirmed by X-ray diffraction analysis. ${ }^{10}$ The optical rotation of compound 1 is similar than the literature indicating the proposed absolute configuration. The antinociceptive activity of bergenin was evaluated by the writhing test. Intraperitoneal administration of bergenin $(12.5-100 \mathrm{mg} / \mathrm{kg}) 30$ min before the acid injection produced a significant $(\mathrm{P}<0.01)$ and dose-related inhibition of acetic acid-induced abdominal constrictions in mice (Figure 2). Indomethacin (10 mg/kg IP), a standard NSAID used as a positive control, produced a similar inhibition of the acetic acid-induced writhing response. The present study demonstrates, for the first time, that the systemic administration of bergenin produces dose-related antinociception when assessed in acetic acid-induced writhing in mice. The writhing test has long been used as a screening tool to assess the analgesic or anti-inflammatory properties of new substances. ${ }^{8}$ Previous pharmacological studies with bergenin showed antiasthmatic, antitussive, anti-inflammatory and antifungal activities, while in vitro trials indicated inhibition of HIV and anti-hepatotoxic activity for this compound. ${ }^{9}$ In addition, the hydroalcoholic extract of Astilbe thunbergii (Saxifragaceae) rhizomes containing bergenin accelerated burn wound healing in mice. ${ }^{11}$

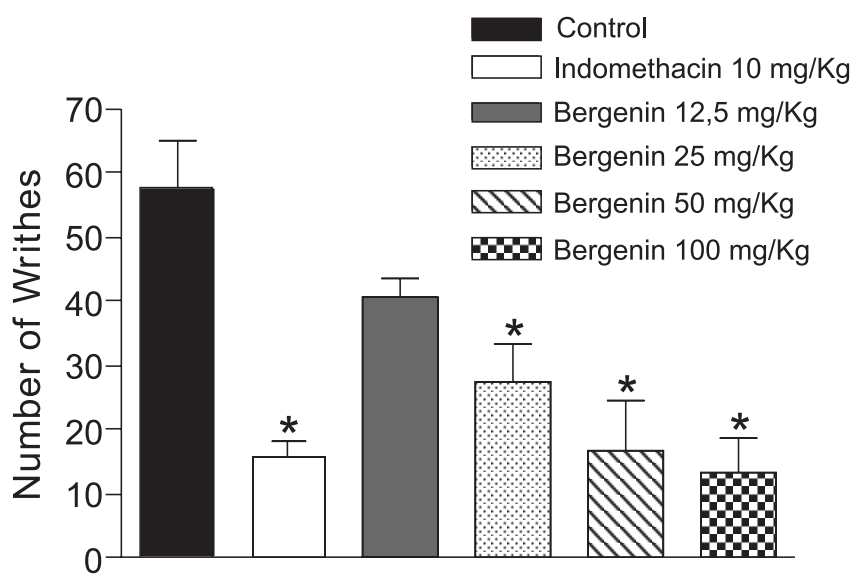

Figure 2. Effect of intraperitoneal administration of bergenin on acetic acid-induced writhing in mice. Swiss mice were treated with bergenin (12.5, 25,50 and $100 \mathrm{mg} / \mathrm{kg}$ ) or saline (control group) by the intraperitoneal route 30 min before treatment with acetic acid $(0.8 \%$, injected at time zero). Indomethacin $(10 \mathrm{mg} / \mathrm{kg} / \mathrm{IP})$ was the reference drug. Data are expressed as means \pm S.E.M.; $n=6$ mice per group. *Significantly different from the control group $(P<0.01)$ as determined by ANOVA followed by Tukey's test

The structure of $\mathbf{3}$ was confirmed by the spectral data obtained by negative [M-H] molecular ion in APCIMS observed at $\mathrm{m} / \mathrm{z}, 615$ besides the resonances registered in ${ }^{1} \mathrm{H}$ and ${ }^{13} \mathrm{C}$ NMR including DEPT. These experiments permitted to propose $\mathrm{C}_{28} \mathrm{H}_{24} \mathrm{O}_{16}$ as molecular formula for this compound. The correlations observed in the HMBC spectra and the variations of chemical shifts of oxymethylene group of glucosyl and C-3 carbon of flavonol moieties and comparison with previous spectroscopic data ${ }^{12}$ permitted to confirm the identity of compound 3. On the same way, the molecular formula for compound $4\left(\mathrm{C}_{30} \mathrm{H}_{26} \mathrm{O}_{14}\right)$ was determinated by combination of the negative molecular ion [M-H] obtained by APCIMS besides ${ }^{1} \mathrm{H}$ and
${ }^{13} \mathrm{C}$ NMR (including DEPT) data analysis. The deshielding observed for the resonances of oxymethylene hydrogens of glucosyl moiety in ${ }^{1} \mathrm{H}$ NMR spectrum and the chemical shift for C-3 of flavonol group indicated the location of these substituents. Comparison with literature ${ }^{13}$ permitted to conclude compound 4 is quercetin -3-O-(6") $O$-E- $p$-coumaroyl)- $\beta$-D-glucopyranoside. The other isolates (Figure 2) were identified by direct comparison of spectroscopic data with previously published data. ${ }^{14}$

Compound 3 (tellimoside) was isolated for the first time from Tellima grandiflora (Saxifragaceae) ${ }^{15}$ this compound is also found in the genera Quercus (Fagaceae), Juniperus (Cupressaceae) and Baseonema (Apocynaceae) ${ }^{16}$ but this is the first reported occurrence in Leguminosae. Helichrysroside (4) was first isolated in the species Helichrysum kraussii (Asteraceae) but this compound was previously found in Pinus sp (Pinaceae), Crocus (Iridaceae) and Melastoma (Maelastomataceae), ${ }^{13}$ but there are no reports of this compound occurring in Leguminosae.

Besides bergenin, gallic acid, present in the bark extract, is also a compound which exhibits antinociceptive, antiinflammatory effects and antioxidant activities. ${ }^{17}$ Bergenin was not isolated from the leaves of C. macrophyllum. However gallic acid and its derivative (ellagic acid) were isolated together quercetin glucoside and its galloyl and coumaryl derivatives. Plants of C. macrophyllum from Caatinga biome were classified until recently under another species, Cenostigma gardnerianum Tul. ${ }^{18}$ They were considered as the same species after an analysis of morphological variation carried out along the entire distribution range. ${ }^{4}$ Our study was performed on Caatinga populations that would be consistent with $C$. gardnerianum of older taxonomic system $\mathrm{s}^{18}$ but the polymorphism in chemical traits demonstrated here raises a question toward a reevaluation of the taxonomic equation.

The literature points out flavonoids as modulating agents and playing regulatory action on inflammation. ${ }^{19}$ To date there is no pharmacological effects described for compounds $\mathbf{3}$ and $\mathbf{4}$ but, compound $\mathbf{3}$ showed different antioxidant activities ${ }^{20}$ and compound $\mathbf{4}$ is a tyrosinase inhibitor. ${ }^{21}$

\section{ACKNOWLEDGEMENTS}

The authors are grateful to the Fundação de Apoio à Pesquisa do Estado da Bahia (FAPESB), the Conselho Nacional de Desenvolvimento Científico e Tecnológico (CNPq) and Coordenação de Aperfeiçoamento de Pessoal de Nível Superior (CAPES) for providing grants and fellowships.

\section{REFERENCES}

1. da Silva, M. F.; Nomes populares das Leguminosas do Brasil, Editora da Universidade Federal do Amazonas: Manaus, 2004.

2. Queiroz, L. P.; Leguminosas da Caatinga, Universidade Estadual de Feira de Santana: Feira de Santana, 2009.

3. Ribeiro, R. C.; Pelacani, C. R.; Sitientibus 2006, 6, 105.

4. Warwick, M. C.; Lewis, G. P.; Edinburgh J. Bot. 2003, 60, 111.

5. Silva, H. R.; da Silva, C. C. M.; Caland Neto L. B.; Lopes, J. A. D.; Cito, A. M. das G. L.; Chaves, M. H.; Quim. Nova 2007, 30, 1877.

6. Sousa, C. M. M.; Silva, H. R.; Vieira-Jr., G. M.; Ayres, M. C. C.; da Costa, C. L. S.; Araújo, D. S.; Cavalcante, L. C. D.; Barros, E. D. S.; Araújo, P. B. M.; Brandão, M. S.; Chaves, M. H.; Quim. Nova 2007, 30, 351 .

7. Zimmermann, M.; Pain 1983, 16, 109.

8. Collier, H. O.; Dinneen, L. C.; Johnson, C. A.; Schneider, C.; Br. J. Pharmacol. Chemother. 1968, 32, 295.

9. Frick, W.; Hofmann, J.; Fischer, H.; Schmidt, R. R.; Carbohydr. Res. 1991, 210, 71 
10. Ye, Y. P.; Sun, H. X.; Pan, Y. J.; Acta Crystallogr., Sect. C: Cryst. Struct. Commun. 2004, 60, 397.

11. Sumiyoshi, M.; Kimura, Y.; Phytomedicine 2010, 17, 820.

12. Masuda, T.; Iritani, K.; Yonemori, S.; Oyama, Y.; Takeda, Y.; Biosci., Biotechnol., Biochem. 2001, 65, 1302.

13. Beninger, C. W.; Abou-Zaid, M. M.; Biochem. System. Ecol. 1977, 25 , 505; Cheng, J. T.; Hsu, F. L.; Chen, H. F.; Planta Med. 1993, 59, 405.

14. Sun, D. W.; Zhao, Z. C.; Wong, H.; Foo, L. Y.; Phytochemistry 1988, 27, 579; Nawwar, M. A. M.; Hussein, S. A. M.; Merfort, I.; Phytochemistry 1994, 36, 793; Li, X. C.; Elsohly, H. N.; Hufford, C. D.; Clark, A. M.; Magn. Reson. Chem.1999, 37, 856; Harbone, J. B.; Mabry, T. J.; Mabry, H. In The Flavonoids: Advances in Research; Harborne, J. B.; Mabry, T. J., eds.; Chapman and Hall: London - New York, 1982, chap. 1, p. 91; Tanaka, J. C. A.; da Silva, C. C.; Dias Filho, B. P.; Nakamura, C. V.; de Carvalho, J. E.; Foglio, M. A.; Quim. Nova 2005, 28, 834; Mendes, C. C.; Bahia, M. V.; David, J. M.; David, J. P.; Fitoterapia 2000, 71, 205;
Bahia, M. V.; dos Santos, J. B.; David, J. P.; David, J. M.; J. Braz. Chem. Soc. 2005, 16, 1402.

15. Collins, F. W.; Bohm, B. A.; Wilkins, C. K.; Phytochemistry 1975, 14, 1099.

16. Romussi, G.; Cafaggi, S.; Bignardi, G.; Pharmazie 1982, 37, 738; De Leo, M.; Braca, A.; de Tommasi, N.; Norscia, I.; Morelli, I.; Battinelli, L.; Mazzanti, G.; Planta Med. 2004, 70, 841.

17. Tunalier, Z.; Koşar, M.; Küpeli, E.; Çaliş, I.; Başer, K. H. C.; J. Ethnopharmacol. 2007, 110, 539.

18. Lewis, G. P.; Legumes of Bahia, Royal Botanic Gardens, Kew: London, 1987.

19. Chirumbolo, S.; Inflamm. Allergy Drug Targets 2010, 9, 263.

20. Sohretoglu, D.; Sakar, M. K.; Sabuncuoglu, S. A.; Ozgunes, H.; Sterner, O.; Turk. J. Chem. 2009, 33, 685.

21. Karioti, A.; Protopappa, A.; Megoulas, N.; Skaltsa, H.; Bioorg. Med. Chem. 2007, 15, 2708. 